\title{
Editorial
}

Richard L. Knill MD

\section{Anaesthesia research: needs for the nineties}

In a span of just over fifty years, scientific research has brought about a host of substantial improvements in the practice of anaesthesia and changed both anaesthesia and surgery beyond recognition. As a result, anaesthesia is no longer the greatly feared cause of surgical morbidity and mortality it once was and anaesthetic care now makes possible the benefits of operative therapy for a wide spectrum of patients, from the completely fit to the very fragile. Over the same fifty-year period, the total volume of anaesthesia research has increased tremendously so that the number of research projects now being undertaken and the number of scientific papers being published have reached remarkable highs. There can be no doubt that anaesthesia research has been an instrument for beneficial change in the care of patients and that the size of the enterprise has grown by leaps and bounds.

These outward signs of success should not be taken to indicate that all is well in the world of anaesthesia investigation. Like other fields of medical research, it is currently faced with difficulties at several levels. University funds for the support of academic activities are shrinking; the time available for scholarly endeavours is decreasing; and the demands for both clinical and administrative services within academic departments continue to grow. As many middle-aged to older investigators reach the end of their academic careers, the prospects for new recruits to academia from potential trainees in the specialty appear dismally low. ${ }^{1}$ Additional to these concerns and particularly worrisome are the serious questions being repeatedly raised about the overall quality of current scientific enquiry in anaesthesia. ${ }^{2-6}$

Following an analysis of a sample of original scientific articles which appeared in the three major North American anaesthesia journals between 1977 and 1986, Cohen and Duncan concluded that the research of this period was "too confined in scope" and that it reflected a "relative shortage of innovative ideas."2 They also judged the range of methodological approaches to be "rather narrow." Other respected leaders of the discipline

From the Department of Anaesthesia, University Hospital and University of Western Ontario, London, Ontario. have expressed similarly candid views about contemporary anaesthesia investigation. Greene has declared that researchers in anaesthesia have developed a penchant for studying "the same tired research subjects again and again, producing variations on a theme and filling in the interstices of knowledge, rather than generating new knowledge."3 He recently contended that the contents of the current anaesthetic literature, when compared with those of journals from earlier periods, show that "the incidence of originality (in research) has decreased while the incidence of triviality has increased." Eger has suggested that a substantial proportion of the present-day anaesthesia investigations that are motivated primarily by a desire for academic advancement are frequently "pedestrian" in nature with findings that "hold little interest." Hamilton has asserted that the science conducted by most anaesthetists has not kept pace with the high standards of medical research in other fields and that anaesthesia is in real danger of seeing the rest of the academic world pass it by. ${ }^{6}$ These perceptions of serious weaknesses in the innovativeness, significance and competitiveness of today's anaesthesia research are obviously generalizations which do not apply throughout the field. Nonetheless, I believe they indicate shortcomings which cannot be ignored.

What can be done to remedy these perceived weaknesses and to foster a wider development of excellence in anaesthesia investigation?* I would like to propose four goals. These goals relate to (1) the range of anaesthesia research interests; (2) the structures of knowledge needed to solve clinical problems; (3) the nature of scientific questions; and (4) the investigative tools required for anaesthesia research. Each goal will be considered in turn.

The first goal is to recognize the wide range of problems that require anaesthesia investigation and to begin

*This Editorial addresses only clinical or "targeted" research - which is research undertaken to solve specific clinical problems. Pure basic or "fundamental" research - which is pursued not to solve problems but to acquire knowledge and understanding for its own sake - will not be considered. 
to explore the many areas which have been previously ignored.

Unlike other clinical disciplines in medicine, anaesthesia has never had a clear-cut definition of its intellectual boundaries. As a result, the largest proportion of its investigative effort has been rather restricted in scope, focused primarily upon those clinical problems which were both conspicuously "anaesthetic" and most worrisome to clinicians. For the most part, these were the problems of providing safety for patients in the immediate perioperative period. In addressing these problems, investigators have directed most of their attention to identifying and describing various physiologic/pharmacologic phenomena which were considered pertinent to understanding and/or managing them. Comparatively little attention has been given to other notable aspects of these problems nor, indeed, to a host of other legitimate concerns. This neglect can be appreciated by considering the broad reach of clinical and scientific problems that require anaesthesia investigation.

The full scope of problems in need of research may be viewed from three perspectives: (1) the domains of clinical interest, (2) the settings of clinical care and (3) an hierarchy of investigative strata for clinical disciplines. By integrating the individual categories of each of these perspectives, it is possible to construct a nosology of research problems that can be depicted as a three dimensional block or "anaesthesia research cube." (Figure).

The domains of clinical interest, depicted along one axis of the cube, are those which were implied by Henry K. Beecher about 35 years ago. These are: (1) the provision of patient comfort, (2) the assurance of patient safety and (3) the facilitation of therapy. ${ }^{7}$ Each of these domains includes a multitude of individual concerns.* The settings of clinical care, shown along the second axis of the cube, can be considered to be: (1) perioperative (i.e., preoperative, operative and early recovery), (2)

*The provision of patient comfort includes not only managing the pain of surgery, childbirth, etc. but extends to preventing and treating many other discomforts - such as anxiety, dysphoria, delirium, nausea and vomiting, "awareness" during operation, fear of blood transfusion, etc. The assurance of patient safety involves not only controlling the major risks of anaesthetic and analgesic states but also managing the critical hazards associated with surgery, the postoperative period, other types of trauma, drug poisoning, pain, childbirth, sepsis, shock, respiratory failure, etc. The facilitation of therapy involves not only the enabling of surgical and childbirth procedures and the recovery therefrom, but also the facilitation of the entire anaesthetic/surgical process as well as enabling various other therapies for critical illness and disorders associated with pain.

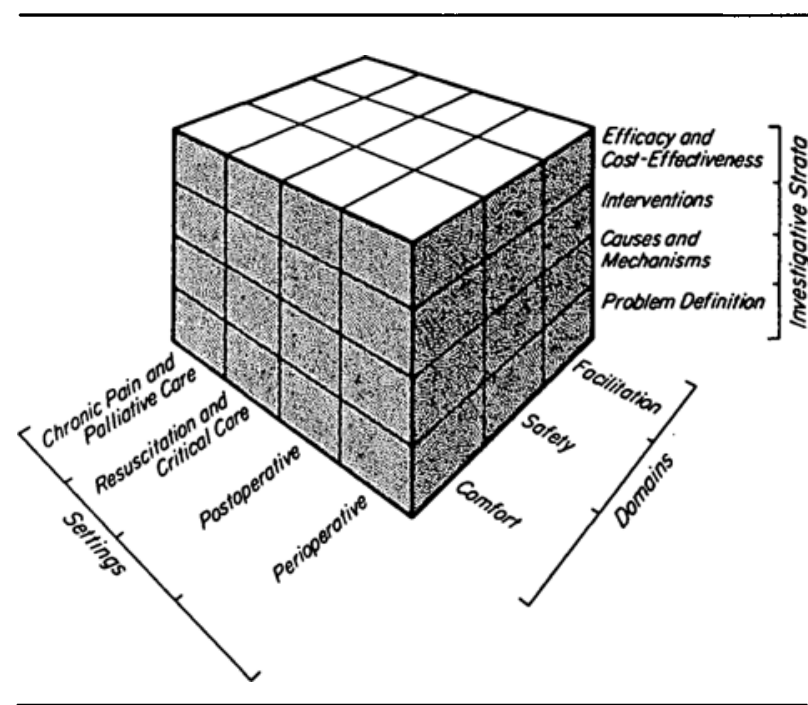

FIGURE The anaesthesia research cube.

postoperative (primarily the first postoperative week, a period of increasing interest for anaesthetists ${ }^{8}$ ), (3) resuscitation and critical care and (4) chronic pain management and palliative care. Notice that anaesthetic interests in the comfort domain and the safety domain apply to all four settings of care, as do certain specific interests in facilitating therapy. The investigative strata, indicated along the vertical axis of the cube, represent the broad objectives of research pursued in solving any problem of clinical medicine. These are: (1) definition of the clinical problem, (2) identification of its causes and mechanisms, (3) development of preventive and therapeutic interventions and (4) assessments of the efficacy of interventions and their cost-effectiveness. Note that each domain/setting combination (i.e., each square at the base of the cube) defines a group of clinical problems for investigation and that each domain/setting/stratum combination (i.e., each block within the cube) denotes a cluster of potential research or scientific problems related to each clinical problem or clinical problem group.

Any consideration of the contents of the anaesthetic literature in relation to this nosology will reveal many striking gaps in our past and current research undertakings. For example, anaesthesia investigators have paid remarkably little attention to numerous clinical problems of providing comfort for patients (e.g., incomplete major nerve blocks, inadequate analgesia upon emergence from general anaesthesia); various problems of facilitating surgery itself (e.g., the unexpected "wet" surgical field, variable effects of neuromuscular blocking agents on the muscles of the abdominal wall); certain "non-surgical" problems of safety which appear in the first postoperative week ${ }^{8}$ (e.g., postoperative myocardial infarction and stroke); and several notable problems of acute resuscita- 
tion (e.g., the need for various means of airway support in the semi-conscious head-injured patient). Indeed, anaesthesia research has barely scratched the surface of whole sections of research problems within this nosology - for example, the definition of many individual problems that constitute anaesthetic morbidity, the causes and mechanisms of the various problems of discomfort in critical care, and the assessments of the cost-effectiveness of virtually all anaesthetic interventions. Anaesthesia investigators need not get bogged down in the wellworn confines of prior research interests. Many important and untouched problems cry out for investigation.

The second goal I put forward for anaesthesia research is to recognize that the ultimate resolution of a clinical problem in medicine depends upon a full understanding of its nature, its genesis and the most effective means of managing it. Such understanding requires a body or "structure" of knowledge derived from study of the four investigative strata referred to above. Thus, to solve a clinical problem, investigators must (1) define the problem clearly, including its clinical appearance and course and its epidemiologic, pathologic and/or pathophysiologic characteristics; (2) identify its causes and mechanisms and the pertinent intermediary processes; (3) develop and test interventions for prevention, detection and/or therapy and (4) assess both the efficacy of the proposed interventions and their cost-effectiveness. Ideally, these layers of information are developed in the logical order indicated, so that findings accrued at each level give stimulus and context for seeking information at the next. In practice, however, the "structure" is usually assembled in a more haphazard way. (It is not uncommon, for example, for therapeutic interventions to be developed and tested before the causes are well understood.) In any case, it is important to appreciate that the ultimate solution to most clinical problems requires a compilation of information based upon studies of most or all of the four investigative strata.

In addressing the clinical problems of anaesthesia, however, investigators have often failed to develop a coherent body of knowledge, usually because they neglected to obtain information at one or more key strata. The result has been important limitations in the understanding of the problems themselves and, in some cases, inadequate or inappropriate recommendations for clinical practice!

Consider the classic problem of the patient with a low preoperative haemoglobin concentration. The clinical dictum held for many years was that elective anaesthesia must not be administered to any patient with a haemoglobin level less than $10 \mathrm{~g} \cdot \mathrm{dl}^{-1}$. This directive was based upon research which had identified the normal arteriovenous oxygen content difference across the heart.
Extrapolating from this observation and the known oxygen-carrying capacity of haemoglobin, clinicians inferred that a haemoglobin concentration less than $10 \mathrm{~g} \cdot \mathrm{dl}^{-1}$ could result in myocardial hypoxia during anaesthesia. However, there was never an investigation to define this hypothesized clinical problem nor a study to show the efficacy of increasing the haemoglobin level in order to avert it. In other words, there was never an attempt to shape a rational structure of knowledge about a subnormal preoperative haemoglobin concentration! As a result, many surgical procedures were unnecessarily cancelled or delayed and many blood transfusions unnecessarily given.

Such defects in structures of knowledge continue to restrict understanding and misguide clinical practice in anaesthesia. It is essential to recognize contemporary examples. Consider the recommendation to control tightly every determinant of myocardial oxygen supply and demand in a patient with any degree of coronary artery disease while undergoing a non-cardiac surgical procedure. This admonition appears to be based upon observations about the physiologic determinants of myocardial oxygen supply and demand. However, this information about mechanisms of myocardial oxygenation seems not to have been accompanied by either a clear definition of a clinical problem of myocardial damage during the course of modern anaesthesia or a study to show the clinical efficacy of the recommended interventions. Consider also the current interest in long-term cognitive impairment in the elderly after anaesthesia and operation. A substantial amount of recent research has attempted to define anaesthetic causes for this problem and to identify management techniques that would prevent it. However, there has not been a controlled study to define the existence of the problem itself, i.e., to see if there is a decrement of cognitive performance after operation that differs from the natural cognitive decline in older persons. Consider further the widely recognized problem of an increased rate of spontaneous abortions in operating room nurses. In this instance, research has defined the existence of the clinical problem and gone on to suggest implementation of waste gas scavenging as a preventive intervention - but the specific cause of the excess abortions has never been identified and the efficacy of the intervention has not been demonstrated. Or finally, consider the problem of inadequately treated postoperative pain. Numerous investigations have assessed the relative efficacies of various kinds of intervention to prevent and/or treat this problem in varied settings. There has, however, never been an adequate definition of the clinical problem itself, to include a systematic identification of the various patient, surgical, and postoperative factors that undoubtedly act as its modifiers and determinants. 
Nor has there been a substantive attempt to examine specific mechanisms of pain and responses to pain in various postoperative contexts.*

Anaesthesia abounds with examples of such fragmentary research which have failed to generate adequate compilations of knowledge about clinical problems and, on that account, left the problems unresolved. Investigators in anaesthesia must appreciate the need to acquire logical structures of knowledge in order to arrive at the most rational and effective solutions to their problems.

The third objective I propose for anaesthesia research is to focus individual research projects upon specific scientific problems or questions that are truly important to the advancement of knowledge. Sir Herman Bondi has written that amongst all scientific problems one might consider for research, about $80 \%$ are insoluble, $19.5 \%$ trivial and only $0.5 \%$ both soluble and important. "It is the task of the scientist to select the tiny layer (of problems) between the insoluble and the trivial where (his or her) skill, insight and originality can make a difference." Too often, researchers in anaesthesia have overlooked their responsibility in this regard and have chosen research problems or questions that lie in the trivial area. On occasion, they have ignored the need for a scientific problem altogether and allowed their "research" to be driven by extraneous factors - such as the availability of a new piece of equipment (the "Have New Instrument, Will Make New Measurement" type of research) or the commercial interests of private industry. It must be remembered that research which leads to substantial advances in knowledge is always focused upon a real scientific problem or question that is both soluble and truly important.

The fourth goal I propose for anaesthesia research is an expansion of research skills and techniques. The traditional reliance of anaesthetists upon the tools of physics, physiology and pharmacology to carry out most of their investigations is no longer adequate nor appropriate. The definition and classification of clinical problems and the assessment of the efficacy and cost-effec-

\footnotetext{
*Readers should be able to extend this list. Think about the available structures of knowledge on the problems of difficult laryngoscopy; interval psychosis after anaesthesia and surgery; prolonged weaning from mechanical ventilation; sudden onset respiratory failure during early recovery from general anaesthesia; and facilitation of surgical access to structures deep within the brain. The reason for the patchy development of knowledge in these and many other areas of anaesthesia is unclear. Perhaps it relates to the instinct of anaesthetists to seek out and implement "quick fixes" to many problems encountered in clinical practice and the unwitting transfer of this kind of approach to research.
}

tiveness of interventions will require the modern concepts and strategies of epidemiology and biostatistics. The identification of causes and mechanisms and the development of effective means of intervention will need not only the techniques of physics, physiology and/or pharmacology but also those of contemporary biochemistry, neuropharmacology, genetics, cellular biology and molecular biology. Efforts are underway to acquire some of these new investigative tools in a few university departments - but such efforts will have to be expanded. Additional skills and techniques from these various disciplines will be crucial to the resolution of many anaesthetic problems.

What specific measures can be taken by investigators, department chairs and others to achieve these goals?

First and foremost, we who are investigators must shed our narrow range of research interests and our inappropriately restrictive approaches to solving problems. We must seek to explore the many important clinical problems of anaesthesia that have been untouched by past research efforts. Some of these problems present marvelous opportunities for new investigation that should appeal to at least the more adventurous among us. We must not be prisoners to the tradition of acquiring only splinters of information about clinical problems - but must commit ourselves to the development of logical structures of knowledge in order to resolve them. We must discipline ourselves to pose scientific questions that have genuine importance and then probe them with the most appropriate investigative tools - being prepared to acquire new skills and techniques if required. In some instances, we may have to learn new methodological techniques ourselves; in other cases, we may be able to engage colleagues from other disciplines who have the necessary skills to join us in our endeavours.

Our university department chairs must promote within their departments and institutions the broader horizons of legitimate anaesthesia research interests. They should identify students, residents and young faculty who have the essential qualities of scholarship (i.e., curiosity, an interest in ideas, independence of mind, enthusiasm and industry) and point out to them the great untapped potential of anaesthesia research. They should inspire new investigators to tackle the previously neglected areas of anaesthesia research and, where possible, offer special support and recognition for efforts in these areas. They should cultivate an awareness of the need for logical structures of knowledge about clinical problems and promote the kinds of investigation that will contribute to them. In advising residents or young faculty on preparing for careers in research, chairs should advocate training programmes that offer exposure to the best mentors and, where possible, to new and needed investigative tech- 
niques. (In some cases, such training objectives will be met only in the laboratories of other disciplines.) Where appropriate, chairs should build bridges to other departments at their institutions with a view to bringing new expertise, needed investigative tools and perhaps other resources to bear upon the study of anaesthetic problems.

Those agencies which fund research and are controlled by anaesthetists, such as the CAS Research Fund, should consider giving preference to the support of investigators who propose studies in the neglected but promising areas.

In my view, if the four goals suggested above were adopted widely, they would have enormous benefits for academic anaesthesia. They would indicate directions and opportunities for many new and important investigations and, in that way, address the recently expressed concerns about a lack of originality and significance in contemporary anaesthesia research. They would equip our investigators with attitudes and values about clinical research that would improve greatly their ability to attract competitive research funding. They would bolster the vitality of anaesthesia research, act to draw greater numbers of talented students and residents into the field and enhance the stature of anaesthesia in the wider academic world.

Most important of all, pursuit of these goals would help ensure what has been the lifeblood of our profession through the past fifty years - and that is progress.

\section{Acknowledgements}

The author wishes to acknowledge the valuable contributions of Drs. D.B. Craig, A.B. Froese, B.J. Mezon, W.K.C. Morgan and W.A. Tweed to the preparation of this manuscript.

\section{La recherche en anesthésie, prospective de fin de siècle}

En un peu plus de cinquante ans, la recherche scientifique a contribué à l'amélioration de la pratique anesthésique, transformant radicalement l'anesthésie et la chirurgie. On n'associe plus anesthésie avec morbidité et mortalité chirurgicale comme par le passé et on peut, grâce à son raffinement, étendre les bénéfices de la chirurgie aux patients les plus fragiles. Durant la même période, les activités de recherche en anesthésie se sont multipliées si bien que maintenant, le nombre des projets de recherche entrepris et le nombre des articles publiés atteignent des sommets. Il ne fait donc pas de doute que la recherche en anesthésie a contribué au bien-être des patients.

Il ne faut cependant pas se leurrer en croyant que tout va pour le mieux dans le monde de la recherche anesthésique car à l'instar d'autres champs de la recherche médicale, les problèmes sont nombreux. Les fonds universitaires ne suffisent plus à soutenir les activités académiques. Les anesthésistes ont de moins en moins de temps à consacrer à l'avancement des connaissances alors qu'ils doivent faire face au sein des départements universitaires à une demande toujours croissante pour des services cliniques et administratifs. Alors que les effectifs des chercheurs en anesthésie se font vieillissants, les perspectives de relève pour les postes académiques en anesthésie ne sont pas rassurantes. ${ }^{1}$ Comme si ce n'était pas assez, on doit aussi s'inquiéter des doutes maintes fois exprimés quant à la valeur de la recherche scientifique actuelle en anesthésie. ${ }^{2-6}$

A partir d'un échantillon d'articles parus dans les trois principaux journaux anesthésiques nord-américains entre 1977 et 1986, Cohen et Duncan concluent que la recherche en anesthésie durant cette période empruntait des avenues limitées et faisait preuve d'un manque d'imagination. ${ }^{2}$ Ils opinaient de même que l'éventail des approches méthodologiques utilisées était plutôt mince. D'autres personnages importants en anesthésie ont aussi exprimé le malaise. Nick Greene prétend que les chercheurs en anesthésie ont développé un penchant pour l' «étude » morne et répétitive des mêmes vieux sujets de recherche qui n'aboutit qu'à d'autres variantes sur un thème éculé. On peaufine de vieilles connaissances plutôt que d'en générer de nouvelles. ${ }^{3}$ Greene ajoutait récemment que lorsque l'on .compare le contenu actuel des journaux d'anesthésie à celui d'époques antérieures, on voit clairement que le ratio originalité/trivialité est à la baisse. ${ }^{4}$ Eger quant à lui affirme qu'un bonne partie de la recherche contemporaine en anesthésie, lorsque motivée surtout par l'avancement académique, vole au ras du sol et que. ses résultats offrent peu d'intérêt. ${ }^{5}$ Hamilton soutient que le niveau moyen de la recherche en anesthésie n'atteint pas les standards élevés de la recherche médicale qu'on observe dans d'autres disciplines et que le danger d'être laissé pour compte par le monde académique est réel. ${ }^{6}$ Tous ces auteurs ont perçu de sérieuses lacunes quant à l'imagination déployée, à l'importance et à la compétitivité de la recherche actuelle en anesthésie qu'il faudrait se garder de généraliser à l'ensemble, néanmoins ils soulignent un problème que je crois bien réel et que nous ferions mieux de regarder en face. 


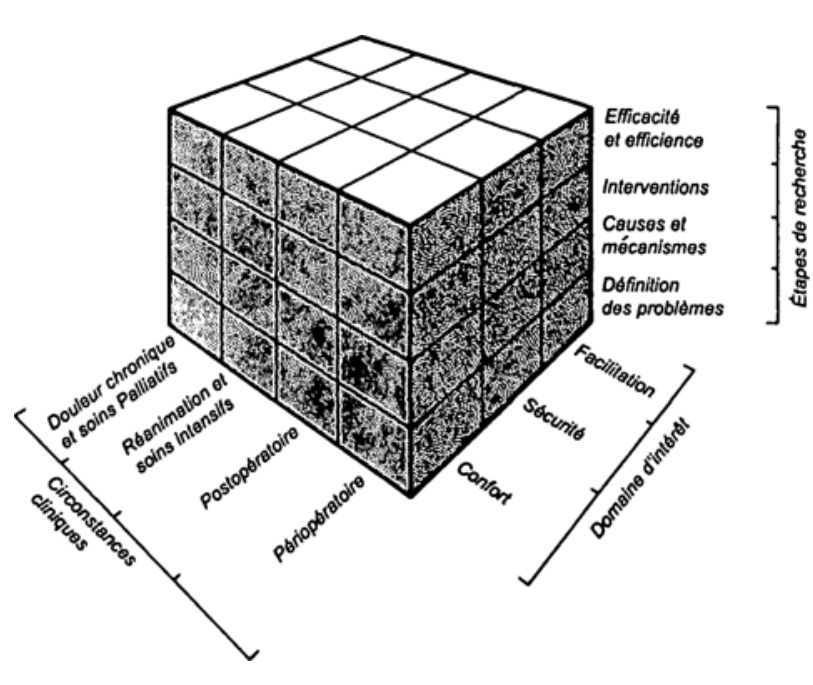

FIGURE Le cube de recherche en anesthésie.

Que peut-on faire pour éradiquer ces déficiences et atteindre l'excellence en recherche anesthésique ?* Je vous propose une réflexion sur quatre thèmes distincts qui ont trait 1) à l'étendue du champ de recherche en anesthésie, 2) à la structure des connaissances nécessaire à la résolution d'un problème clinique, 3) à la nature scientifique des questions et enfin 4) aux outils nécessaires à la recherche en anesthésie. Je traiterai de ces quatre thèmes tour à tour.

Premièrement, on doit prendre conscience du grand nombre de problèmes pouvant faire l'objet de recherches en anesthésie et commencer à explorer ces avenues ignorées jusqu'à ce jour. Contrairement à plusieurs disciplines médicales, on n'a jamais défini clairement les frontières intellectuelles de l'anesthésie, si bien que pour la plupart, les études entreprises avaient des prétentions limitées et se concentraient surtout sur les problèmes qui, inquiétants aux yeux des cliniciens, avaient une dimension «anesthésique» évidente. Ces questions avaient surtout trait à la sécurité des patients en période périopératoire immédiate. Les chercheurs dirigeaient alors leurs efforts sur l'identification et la description de divers phénomènes physiologiques et/ou pharmacologiques qu'ils croyaient nécessaires de comprendre et de contrôler. Ce faisant, ils négligeaient divers aspects importants de ces mêmes problèmes et ils éludaient une myriade de questions valables. On peut entrevoir les conséquences de cette approche à courte vue en tentant de saisir

*Cet éditorial traite de recherche clinique, celle dont le but est de résoudre des problèmes cliniques précis. La recherche pure ou fondamentale qui ne vise pas la résolution de problème mais plutôt l'acquisition de nouvelles connaissances ne fait pas l'objet de notre propos. l'ampleur des problèmes cliniques et scientifiques dont la résolution requiert que les anesthésistes se relèvent les manches.

On peut tenter de décrire cet ensemble de problèmes à résoudre à partir de trois perspectives différentes: 1) le domaine d'intérêt clinique, 2) les circonstances cliniques, 3) l'ordre des étapes en recherche clinique. Selon les coordonnées établies à l'échelle de ces trois perspectives, on peut classifier ces problèmes sur une matrice tridimensionnelle, sur un «cube de recherche en anesthésie ». (Figure).

Les domaines d'intérêt clinique représentés sur un axe du cube sont ceux décrits par Henry K. Beacher il y a 35 ans. Ce sont: 1) le confort du patient, 2) sa sécurité et 3) la facilitation de l'intervention thérapeutique. ${ }^{7}$ Chacun de ces domaines peut évidemment être subdivisé plus avant. $\dagger$ Les circonstances cliniques, illustrées sur le deuxième axe du cube peuvent être circonscrites à: 1) la période périopératoire (préopératoire, opératoire et postopératoire immédiate), 2) la période postopératoire (surtout la première semaine, qui suscite d'ailleurs un intérêt grandissant chez les anesthésistes, ${ }^{8} 3$ ) la réanimation et les soins intensifs et 4 ) les soins palliatifs et les problèmes de douleur chronique. Il est à noter que les domaines d'intérêt que sont le confort et la sécurité des patients de même que certaines aspects de la facilitation de l'intervention peuvent être abordés lors de toutes les circonstances décrites plus haut. L'ordre des étapes de recherche représenté sur l'axe vertical du cube illustre les grands objectifs de recherche que l'on doit atteindre afin de solutionner un problème clinique en médecine. Tout d'abord, il faut 1) définir le problème clinique ensuite, 2) on doit en identifier les causes et en expliquer les mécanismes puis, 3) on développe les mesures préventives et thérapeutiques appropriées et enfin, 4) on évalue

†Assurer le confort du patient signifie plus que de calmer la douleur de l'opération et de l'accouchement etc. Il faut aussi s'occuper des autres visages de l'inconfort: l'anxiété, la dysphorie, le délire, les nausées et les vomissements, la " conscience » per-opératoire, la peur des transfusions etc. Assurer sa sécurité implique non seulement le contrôle des risques majeurs associés aux états anesthésiques et à l'analgésie mais aussi celui des dangers liés à l'intervention chirurgicale, à la période postopératoire, aux traumatismes, aux empoisonnements, à la douleur, à l'accouchement, à l'infection, au choc, à la défaillance respiratoire, etc. La facilitation de l'intervention thérapeutique ne se limite pas à rendre possible une intervention chirurgicale ou un accouchement et la récupération qui s'ensuit; elle trouve aussi sa place lors de toute intervention douloureuse ou risquée. Aussi, c'est tout le déroulement du processus anesthésio-chirurgical qui peut faire objet de réflexion. 
l'efficacité et l'efficience (rapport coûts/bénéfices) de ces mesures. Ainsi, chaque combinaison domaine-circonstance (chaque carré à la base du cube) détermine un groupe de problèmes cliniques à résoudre et chaque combinaison domaine-circonstance-étape (chacun des blocs du cube) invite à la résolution d'un sous-ensemble de problèmes d'ordre scientifique découlant du problème ou du groupe de problèmes d'ordre clinique.

La confrontation de la littérature anesthésique avec cette grille d'analyse permets d'observer les nombreux «trous» laissés béants par nos entreprises de recherche passées et présentes. Ainsi, les chercheurs en anesthésie ont pratiquement négligé de nombreux problèmes relevant du domaine du confort (ex.: blocs nerveux incomplets, analgésie insuffisante lors de l'émergence de l'anesthésie) et d'autres ayant trait à la facilitation des interventions chirurgicales (ex. : champ opératoire remarquablement sanguinolent, effets variables des myorelaxants sur la musculature abdominale). Ils n'ont pas fait mieux avec de nombreux problèmes de sécurité «nonchirurgicaux » survenant durant la première semaine après l'intervention chirurgicale ${ }^{8}$ (ex.: infarctus cérébral ou myocardique) non plus qu'avec d'autres survenant dans un contexte de réanimation (ex.: la nécessité de développer divers moyens d'assurer la perméabilité des voies respiratoires chez les traumatisés crâniens semiconscients). De fait, la recherche anesthésique a presque totalement ignoré plusieurs secteurs de cet univers de recherche potentiel représenté par le «cube» tels la définition des différents problèmes de morbidité anesthésique, les mécanismes et causes des divers problèmes d'inconfort aux soins intensifs ainsi que l'évaluation de l'efficience d'à peu près toutes les interventions anesthésiques. Il est donc ridicule pour les chercheurs de se confiner aux secteurs déjà bien connus. De nombreux problèmes importants méritent qu'enfin on y réfléchisse.

Deuxièmement, les anesthésistes et à fortiori les chercheurs en anesthésie doivent reconnaître que la résolution complète d'un problème clinique en médecine présuppose la compréhension de sa nature, de son étiologie et la connaissance des solutions les plus efficaces. La dite compréhension requiert un corpus de connaissances tirées des quatre étapes de recherche dont on a discuté plus haut. Ainsi, afin de résoudre un problème clinique, les chercheurs doivent 1) définir clairement le problème avec ses aspects cliniques, son histoire naturelle, son épidémiologie et ses caractéristiques pathologiques et/ou physiopathologiques; 2) en identifier les facteurs étiologiques et en décrire les mécanismes ; 3) développer des modes de prévention, de détection et d'intervention thérapeutique; 4) évaluer l'efficacité et l'efficience des modes proposés. Idéalement, ces diverses couches d'informations devraient se déposer les unes sur les autres en un ordre logique de telle sorte que les trouvailles faites à une étape dirigent naturellement les recherches à entreprende à l'étape suivante. Malheureusement, cette structure idéale pour l'avancement des connaissances n'est pas toujours respectée ainsi, il n'est pas rare que l'on développe et évalue des interventions thérapeutiques avant de cerner l'étiologie du problème. Cela étant dit, il importe de réaliser que l'ultime solution de la plupart des problèmes d'ordre clinique requiert la compilation d'informations glanées à partir d'études couvrant toutes (ou presque) ces étapes de recherche.

Pourtant, en anesthésie, les chercheurs cliniques n'ont souvent pas réussi à assembler un corpus cohérent de connaissances au sujet d'un problème, et ce parce qu'il négligeaient une ou des étapes logiques de la stratégie de recherche. Il en est résulté une compréhension incomplète du problème en cause et des recommandations de pratique inadéquates ou carrément inappropriées!

Prenons l'exemple du problème classique que pose le patient qui présente une hémoglobine basse en préopératoire. Le bon vieux dicton voulait qu'on évite d'entreprendre une anesthésie élective chez tout patient dont la concentration sanguine en hémoglobine était inférieure à $10 \mathrm{~g} \cdot \mathrm{dl}^{-1}$. Cette recommandation trouvait son fondement dans une étude qui avait évaluée la différence artérioveineuse normale du contenu en oxygène du sang au niveau du coeur. En extrapolant à partir de ces mesures et de la capacité connue de transport de l'oxygène par l'hémoglobine, des cliniciens bien intentionnés présumèrent qu'une concentration en hémoglobine inférieure à 10 $\mathrm{g} \cdot \mathrm{dl}^{-1}$ risquait d'entraîner de l'hypoxie myocardique pendant l'anesthésie. Jamais pourtant n'a t'on vu une étude visant à définir l'existence réelle de ce problème clinique hypothétique non plus qu'à vérifier qu'en augmentant la concentration en hémoglobine, on arrivait à prévenir le dit phénomène. En d'autres termes, on n'a jamais tenté de construire une structure rationnelle de connaissances autour d'une concentration en hémoglobine inférieure à la normale en préopératoire et on a probablement retardé ou annulé indûment de nombreuses interventions chirurgicales sans parler de la quantité de sang transfusé inutilement.

Ce type de déficiences dans la structure de nos connaissances continue d'entraver notre compréhenșion des problèmes et fait dévier la pratique clinique en anesthésie. En voici quelques exemples plus contemporains. On se croit généralement justifié de contrôler rigoureusement toutes les variables déterminant la demande et l'apport d'oxygène au coeur lors d'une intervention chirurgicale chez un coronarien. Cette recommandation nous vient probablement de l'observation des différents facteurs physiologiques déterminant la 
consommation et l'apport d'oxygène au niveau du myocarde. Pourtant, cette information sur les mécanismes de l'oxygénation myocardique ne saurait se substituer à la documentaiton claire qu'il existe réellement un problème clinique de lésion myocardique survenant lors d'une anesthésie moderne. Il n'existe pas non plus d'évaluation de l'efficacité clinique des interventions recommandées. Il en va de même de l'intérêt que certains portent aux déficits cognitifs à long terme survenant chez le vieillard après une anesthésie et une opération. Plusieurs études récentes tentent d'identifier les causes anesthésiques du problème et de cerner les techniques les plus appropriées. Pourtant, l'existence même de ce soidisant problème reste à démonter dans le cadre d'une étude bien contrôlée qui évaluerait la diminution des performances cognitives des vieillards opérés en la comparant à la diminution naturelle de ces performances survenant chez les personnes âgées en général. Que dire du problème, bien connu celui-là, du nombre d'avortements spontanés élevé chez les infirmières de salle d'opération? Les chercheurs ont, dans ce cas, bien défini l'existence réelle d'un problème et ont suggéré la mise sur pied systématique de systèmes de récupération des gaz anesthésiques à titre de mesure préventive. Cependant, l'étiologie exacte de l'excès d'avortements demeurait inconnue et l'efficacité des moyens mis en oeuvre n'était pas démontrée. Abordons enfin le problème des douleurs postopératoires mal soulagées. De nombreuses études ont évalué l'efficacité relative de plusieurs types d'intervention visant à prévenir ou à traiter ce problème en diverses circonstances. Pourtant, on a jamais bien défini le problème clinique en tant que tel alors qu'il faudrait pouvoir cerner les facteurs individuels, chirurgicaux et postopératoires qui le modulent. Un examen systématique des mécanismes spécifiques de la douleur et de ses conséquences en divers contextes postopératoires se fait encore attendre.*

L'anesthésie regorge d'exemples de ce type de recherche fragmentaire qui n'arrive pas à générer et à organiser de façon adéquate les connaissances nécessaires à la

* Le lecteur devrait pouvoir allonger cette liste. Pensez à la structure des connaissances concernant l'intubation difficile; la psychose postopératoire ; le sevrage difficile du respirateur mécanique; la défaillance respiratoire soudaine à l'émergence de l'anesthésie générale; la facilitation de l'approche chirurgicale des structures cérébrales situées en profondeur. Comment expliquer le développement erratique des connaissances de ces chapitres (entre autres) de l'anesthésie ? Cela tient peut-être à l'instinct de l'anesthésiste qui doit souvent trouver une solution immédiate à une variété de problèmes survenants en pratique. Cette approche de «dépanneur» se transpose probablement mal en recherche. résolution des problèmes cliniques. Les chercheurs en anesthésie doivent reconnaître l'importance de développer une structure logique de connaissance afin de trouver les solutions rationnelles et efficaces aux problèmes cliniques réels.

Troisièmement, en anesthésie, nous ferions mieux de diriger nos efforts de recherche vers les questions qui sont vraiement importantes pour l'avancement des connaissances. Sir Herman Bondi écrivait que parmi tous les problèmes scientifiques susceptibles d'attirer les chercheurs, $80 \%$ étaient insolubles, $19,5 \%$ étaient insignifiants ce qui n'en laisse que $0,5 \%$ qui sont à la fois solubles et importants. «C'est le rôle du vrai chercheur que de s'installer entre l'insoluble et la banalité, dans cette mince couche de problèmes que son intelligence peu contribuer à résoudre. $)^{9}$ Trop souvent, les chercheurs en anesthésie ont abdiqué cette responsabilité et se sont attardé à des problèmes insignifiants. Parfois même, ils ont éludé le besoin de s'attaquer à un problème scientifique pour laisser leur activité de recherche être dirigée de l'extérieur par la disponsibilité d'une nouvelle pièce d'équipement ( si on mesurait avec ça pour voir ») ou l'intérêt commercial de l'industrie. Pour contribuer de façon importante à l'avancement des connaissances, la recherche doit toujours s'attaquer à une question ou à un problème scientifique à la fois résoluble et important.

Quatrièmement, il faut réaliser qu'en recherche anesthésique nous devons diversifier nos compétences et nos techniques. On ne peut plus de nos jours se limiter à la physique, à la physiologie et à la pharmacologie pour répondre aux questions qui nous intéressent. La définition et la classification des problèmes cliniques de même que l'évaluation de l'efficacité et de l'efficience des solutions qui leur sont apportées requiert l'apport de l'épidémiologie et de la biostatistique. L'identification des causes et mécanismes des problèmes ainsi que le développement de moyens d'intervention efficaces devra faire appel au delà de la physique, de la physiologie et de la pharmacologie, aux sciences que sont devenues la biochimie, la neuropharmacologie, la génétique, la biologie cellulaire et la biologie moléculaire. Certains départements universitaires commencent à faire appel à ces nouvelles techniques mais ils sont encore trop peu nombreux. Plusieurs problèmes anesthésiques ne trouveront leur solution qu'avec l'apport de ces diverses disciplines.

Pratiquement, quelles mesures spécifiques les chercheurs, directeurs de départements et autres peuvent-ils prendre afin d'intégrer cette réflexion en quatre volets sur l'avenir de la recherche en anesthésie? D'abord et avant tout, les chercheurs parmi nous doivent aller au delà de leurs intérêts de recherche traditionnels et élargir 
leur approche méthodologique. Sortons des sentiers battus pour nous attaquer aux nombreux problèmes importants qui embêtent l'anesthésiste et qui sont restés sans réponse jusqu'à ce jour. Certains de ces problèmes présentent un fantastique créneau à explorer, ce qui devrait au moins attirer les plus braves d'entre nous. Il faut se débarrasser de cette habitude de collectionner des bribes d'information sur un problème clinique et nous astreindre à développer à son sujet une structure conceptuelle organisée et logique. Il faut poser les bonnes questions, celles qui sont importantes, puis les aborder avec les outils les plus appropriés même si cela nécessite que l'on apprenne de nouvelles techniques pour ce faire. Il faudra sans doute acquérir ces nouvelles aptitudes nous mêmes en certaines occasions alors qu'en d'autres cas, nous devrions pouvoir nous associer à des chercheurs d'autres disciplines qui auront des compétences utiles à la résolution de nos problèmes.

Nos chefs de départements universitaires doivent, à l'intérieur de leurs départements et de leurs institutions, se faire les champions d'une recherche aux horizons élargis. Ils devraient aussi déceler parmi les étudiants, les résidents et les jeunes patrons ceux qui ont des qualités académiques (curiosité, capacité de réflexion, indépendance d'esprit, enthousiasme et obstination) et leur faire valoir qu'il existe des champs encore vierges pouvant se prêter à la recherche en anesthésie. Ils devraient inciter les jeunes chercheurs à explorer ces zones négligées jusqu'à ce jour et lorsque possible, les supporter activement en ce sens. Ils devraient insister sur l'importance de la structuration logique des connaissances et susciter la recherche qui y contribue. C'est aussi leur rôle que d'encourager les résidents et patrons qui se préparent à une carrière en recherche, à s'exposer aux plus beaux esprits de la spécialité et à acquérir les nouvelles compétences méthodologiques dont ils auront besoin en allant, s'il le faut, les chercher dans les laboratoires d'autres disciplines. Enfin, lorsqu'indiqué, nos chefs universitaires devraient cultiver leurs relations avec les autres départements de leur institution afin d'aller y puiser une expertise, des outils de recherche et autres ressources qui s'avéreront utile à la recherche en anesthésie.

Les fonds de recherche dont les anesthésistes ont le contrôle tel le Fond de Recherche de la SCA devraient supporter préférentiellement les chercheurs qui s'engagent sur de nouvelles et prometteuses avenues.

A mon sens, si on s'inspirait largement des quatre points dont $\mathrm{j}$ 'ai traité, l'académisme en anesthésie en retirerait d'énormes avantages. Ils pourraient indiquer la direction à prendre et souligner plusieurs occasions d'entreprendre des études inédites et importantes, répondant ainsi aux récentes critiques sur le manque d'originalité et la banalité de la recherche actuelle en anesthésie. Les chercheurs en anesthésie y trouveraient des attitudes concernant la recherche clinique leur permettant d'être plus compétitifs auprès des bailleurs de fonds. La recherche en anesthésie en serait revitalisée et elle pourrait plus facilement attirer les étudiants et les résidents les plus talentueux. La stature de l'anesthésie au sein du monde académique n'en serait que grandie.

Finalement, la poursuite de cet idéal assurerait la perénnité de ce qu'il y a eu de plus vital au sein de notre profession durant ces cinquante dernières années et ça, c'est le progrès.

\section{Remerciements}

L'auteur tient à remercier D.B. Craig, A.B. Froese, B.J. Mezon, W.K.C. Morgan et W.A. Tweed pour leur contribution à la préparation de ce manuscrit.

\section{References}

1 Ryten $D$. The place of research in the career goals of medical students in Canada. The Association of Canadian Medical Colleges, Ottawa, Canada, 1986; 23.

2 Duncan PG, Cohen MM. The literature of anaesthesia; what are we learning? Can J Anaesth 1988; 35: 494-9.

3 Greene NM. Anaesthesiology research. A workshop report. In: Black EA, Deming PA (Eds.). DHEW Publication No. (NIH) 77-80, 1076; 109.

4 Greene NM. Anesthesiology journals, 1992. Anesth Analg $1992 ; 74 ; 116-20$.

5 Eger RI. Am I interested in anaesthesia research? A workshop for residents in anaesthesia. Canadian Anaesthetists' Society Annual Meeting. Vancouver B.C. June 18, 1990.

6 Hamilton WK. Does a legalistic approach to anaesthesia benefit the patient? Ann R Coll Physicians and Surg Engl 1988; 70: 352-6.

7 Beecher HK, Todd DP. A study of the deaths associated with anaesthesia and surgery. Ann Surg 1954; 140: 2-34.

8 Knill RL. Clinical research in anaesthesia. Past accomplishments and a future horizon (Editorial). Anaesthesia 1990; 45: 271-2.

9 Bondi $H$. Newton and the twentieth century - a personal view. In: Fauvel J, Flood R, Shortland M, Wilson R (Eds.). Let Newton Be! New York: Oxford University Press, 1988: 241-8. 